\title{
Development of a novel health drink from millets
}

\author{
S. PARVATHI*, M. NITHYA AND R. YOGESHWARI \\ Department of Home Science Extension, Home Science College and Research Institute (T.N.A.U.) \\ MADURAI (T. N.) INDIA(Email : parvathi_in1957@yahoo.com)
}

\begin{abstract}
Small millets have immense health benefits as they are rich in phytochemicals and nutrients, particularly beneficial to overcome the current life style diseases. On the other hand, in India more than 50 per cent of children are malnourished. Millet based foods help to overcome these two extremes. Millet based products is economically viable and also it highlights the excellent medicinal and nutritional qualities. An attempt was made to develop millet health drink using germinated pearl millet, kodo millet and whole wheat along with pulses. The grains were soaked in water for $3 \mathrm{~h}$ and allowed to germinate for $24 \mathrm{~h}$ followed by shade dried for $10 \mathrm{~h}$. The dried germinated millets were roasted until husks spilt open and then milled in a burr mill to obtain a fine flour. The flour was then blended with green gram flour, roasted bengal gram flour and skim milk powder. For the standardized health mix, DPPH scavenging activity, product properties such as bulk density, water solubility index and swelling index, proximate composition were studied and also sensory evaluation was conducted for the health drink prepared by using the standardized health mix. DPPH scavenging activity of the health mix was found to be $0.664 \pm 0.08 \mathrm{mg} / \mathrm{g}$. Bulk density, water solubility index and swelling were calculated as $0.85 \mathrm{~g} / \mathrm{cm}^{3}, 9$ and 1 per cent, respectively. The standardized mix had 17.08 per cent protein, 4.05 per cent fibre, $20.68 \mathrm{mg}$ calcium and $7.57 \mathrm{mg}$ of iron in $100 \mathrm{~g}$. The drink had high consumer acceptability. The nutrient rich health drink was suitable for all groups of people. The mix can be used for preparation of different snacks like sweet ball, steamed food etc.
\end{abstract}

KeY Words : Millets, Health food mix, Health drink, Nutrients, Anti oxidant activity

View Point Article : Parvathi, S., Nithya, M. and Yogeshwari, R. (2015). Development of a novel health drink from millets. Internat. J. Home Sci. Extn. \& Comm. Manage., 2 (2): 90-94.

Article History : Received : 21.02.2015; Revised : 21.05.2015; Accepted : 22.06.2015 